\title{
Investigate the Corrosion Inhibition of Mild Steel in Sulfuric Acid Solution by Thiosemicarbazide
}

\author{
Fatma Mohamed Mahgoub ${ }^{1,2 *}$, S. M. Al-Rashdi ${ }^{3}$ \\ ${ }^{1}$ Chemistry Department, Faculty of Science, King Abdulaziz University, Jeddah, KSA \\ ${ }^{2}$ Institute of Graduate Studies and Research, University of Alexandria, Alexandria, Egypt \\ ${ }^{3}$ Chemistry Department, Faculty of Science, Umm Al-Qura University, Makka, KSA \\ Email: *ftm mahgoub@yahoo.com
}

Received 16 May 2016; accepted 17 July 2016; published 20 July 2016

Copyright (C) 2016 by authors and Scientific Research Publishing Inc.

This work is licensed under the Creative Commons Attribution International License (CC BY). http://creativecommons.org/licenses/by/4.0/

(c) (i) Open Access

\begin{abstract}
Corrosion inhibition of mild steel in $0.5 \mathrm{~mol} / \mathrm{L} \mathrm{H}_{2} \mathrm{SO}_{4}$ was investigated in the absence and presence of different concentrations of thiosemicarbazide. The inhibition efficiency of thiosemicarbazide was studied by electrochemical impedance methods, potentiodynamic polarization and scanning electron microscopy at different inhibitor concentrations. Inhibition efficiency, corrosion rate and surface coverage were evaluated at different concentrations of thiosemicarbazide. Electrochemical impedance plots indicated that the presence of the inhibitors increased the charge transfer resistance of the corrosion process, increasing the inhibition efficiency. Polarization curves showed that this compound acted as mixed type inhibitor. The results of the investigation showed that this compound had good inhibiting properties for mild steel corrosion in $0.5 \mathrm{M}$ sulfuric acid. The adsorption isotherm studies showed that Thiosemicarbazide adsorbed chemisorbed and formed a stable surface complex on the mild steel surface. And Langmuir obeyed the adsorption isotherm. Scanning electron microscopy analysis shows that, the surface morphology of the polished mild steel in the presence of thiosemicarbazide as inhibitor is smoother surface as compared with polished mild steel specimen in the absence of inhibitor.
\end{abstract}

\section{Keywords}

Acidic Medium, Adsorption, Inhibitor Mild Steel and SEM

${ }^{*}$ Corresponding author.

How to cite this paper: Mahgoub, F.M. and Al-Rashdi, S.M. (2016) Investigate the Corrosion Inhibition of Mild Steel in Sulfuric Acid Solution by Thiosemicarbazide. Open Journal of Physical Chemistry, 6, 54-66.

http://dx.doi.org/10.4236/ojpc.2016.63006 


\section{Introduction}

The corrosion of materials is one of the main problems facing industrial processes, generating huge financial losses. Metallic industrial structures are often exposed to conditions that facilitate corrosive processes. Acid solutions are used in industries for pickling, acid cleaning and de-scaling of steel components. Acidizing inhibitors are added to protect the base metal from corrosion [1]. The use of organic inhibitors for preventing corrosion is a promising solution [2]. These organic inhibitors are usually adsorbed on the metal surface by the formation of a coordinate covalent bond (chemical adsorption) or the electrostatic interaction between the inhibitor and the metal (physical adsorption) [3]. These compounds were adsorbed, or formed a protective layer/insoluble complex on the metal surface and block the active corrosion sites [4].

Earlier studies have shown that the adsorption mainly depends on the p-electrons or d-electrons and on the heteroatom of the molecule which induces greater adsorption of the inhibitor molecules onto the surface of mild steel. Most of the effective organic compounds bearing heteroatoms with high electron density such as phosphorus, sulfur, nitrogen, oxygen, which are considered as adsorption centers, are effective inhibitors for the corrosion of metals [5]-[8]. In recent years, the efficiency of thiosemicarbazones compounds as organic corrosion inhibitors has been studied in a widely range [9]-[15]. The possibility to form complexes with different metals has also been reported [16]-[18]. The high activity and efficiency of these compounds against corrosion was due to the presence of both nitrogen and sulfur in their structures, generating higher inhibition efficiencies when compared to compounds containing only one of these elements. In addition, sulfur-containing compounds are generally more active than oxygen-containing compounds of similar structure [19] [20].

In this study, the adsorption and the inhibitory efficiency of thiosemicarbazide against the corrosion of mild steel in $0.5 \mathrm{~mol} / \mathrm{L}$ of $\mathrm{H}_{2} \mathrm{SO}_{4}$ solutions were investigated. Potentiodynamic polarization, electrochemical impedance techniques and scanning electron microscopy analysis were studied.

\section{Experimental Technique}

\subsection{Preparation of Inhibitor Solution}

The stock solution of $0.1 \mathrm{M}$ inhibitor (thiosemicarbazide) was prepared. The mild steel rod was used as working electrode, which was cut from a cylindrical mild steel rod to a length of about $5 \mathrm{~cm}$ with chemical composition are : C (0.16), Si (0.13), Mn (0.7), P (0.019), Cr (0.016), Ni (0.007), Cu (0.077), Mo (0.008), Al (0.016), V (0.003), $\mathrm{Ag}(0.014)$ and $\mathrm{Fe}$ (remainder). A metallic wire is attached with the specimen then the wire was covered with glass tube which separated the wire from the environment. Then, it fixed in Teflon rods of proper internal diameter by epoxy resin so that only its cross section $\left(0.785 \mathrm{~cm}^{2}\right)$ was allowed to contact the test solution. Before the measurements, the surface of mild steel were polished using different grades of silicon carbide paper stating with a coarse one (80) and proceeding into finer grade (2000) and rinsed with deionized water before each experiment, and dried.

\subsection{Electrochemical Measurements}

The assays were performed at room temperature using a three electrode electrochemical cell containing the mild steel rod as working electrode with a $0.785 \mathrm{~cm}^{2}$ surface area, a platinum auxiliary electrode and a silver-silver chloride $(\mathrm{Ag} / \mathrm{AgCl}, 3.0 \mathrm{M} \mathrm{KCl})$ reference electrode. The potentiodynamic polarization curves and electrochemical impedance spectroscopy (EIS) measurements were performed using (ACM Gill AC) potentiostat/galvanostat under computer control. The working electrode was immersed in test solution for $17 \mathrm{~min}$ to establish a steady state open circuit potential $\left(\mathrm{E}_{\text {ocp }}\right)$. After measuring the $\mathrm{E}_{\mathrm{ocp}}$, the electrochemical measurements were performed. The EIS experiments were conducted in the frequency range of $10 \mathrm{kHz}$ to $10 \mathrm{mHz}$. The amplitude was $10 \mathrm{mV}$. The polarization curves were obtained in the potential ranges from $-700 \mathrm{mV}$ to $-200 \mathrm{mV}$ with a scan rate at $30 \mathrm{mV} \cdot \mathrm{s}^{-1}$.

\subsection{Scanning Electron Microscopy}

The surface morphology of the formed layers on the mild steel surface after its immersion in the solutions of 0.5 $\mathrm{M} \mathrm{H}_{2} \mathrm{SO}_{4}$ in the absence and in the presence of the inhibitor $(0.1 \mathrm{M})$ was carried out. The specimens were taken out, and dried and the SEM photographs of the surfaces of the specimens were investigated by JSM-6360 LV instrument. 


\section{Results and Discussion}

\subsection{Electrochemical Impedance Spectroscopy (EIS)}

The corrosion behaviour of mild steel in $0.5 \mathrm{M} \mathrm{H}_{2} \mathrm{SO}_{4}$ solution, in the absence and presence of thiosemicarbazide, was investigated by the electrochemical impedance spectroscopy measurements (EIS) at different temperature $30^{\circ} \mathrm{C}, 40^{\circ} \mathrm{C}, 50^{\circ} \mathrm{C}$ and $60^{\circ} \mathrm{C}$ after an exposure time of $20 \mathrm{~min}$. The Nyquist plots for different inhibitor concentrations at different temperature are shown in Figure 1. The electrochemical impedance data from the Nyquist plots are given in Table 1.

The Nyquist diagrams show a single semicircle shifted along the real impedance axis $\left(Z_{\text {real }}\right)$, indicating that the corrosion of mild steel in $0.5 \mathrm{M} \mathrm{H}_{2} \mathrm{SO}_{4}$ solution is controlled by a charge-transfer process [21]. And the impedance response (diameter of the semicircle) of mild steel in inhibited solution has significantly changed after the addition of thiosemicarbazide in the corrosive media, and the impedance of inhibited substrate increased with increasing thiosemicarbazide concentration.

The charge-transfer resistance values $\left(R_{c t}\right)$ were obtained from the $Z_{\text {real }}$. The higher-frequency intersection corresponds to the solution resistance $\left(R_{s}\right)$, and the lower-frequency intersection corresponds to $R_{s}+R_{c t}$. Thus, Rct values were calculated as the difference between the high-and low-frequency intersection values [22]. The double layer capacitance $\left(C_{d l}\right)$ and the frequency at which the imaginary component of the impedance is maximal are found as represented in equation [23]:

$$
C_{d t}=\frac{1}{2 \pi f_{\max } R_{c t}}
$$

where $f_{\max }$ is the frequency value at which the imaginary component of the impedance is greatest. And the inhibition efficiency got from the charge transfer resistance is calculated by:

$$
\% I E=\left[1-\frac{\left(1 / R_{c t}\right)}{\left(1 / R_{c t}\right)_{o}}\right] \times 100
$$

where $\left(R_{c t}\right) \&\left(R_{c t}\right)_{O}$ are the charge transfer resistances in the absence and presence of the selected concentrations of corrosion inhibitor respectively. In Figure 3, the deviation from an ideal semicircle is generally attributed to the frequency dispersion as well as to the inhomogeneities of surface and mass transport resistant [24]. The diameter of the capacitive loop increased in the presence of the inhibitors. Table 1 showed that, the $R_{c t}$ values of inhibited substrates are increased with the concentration of inhibitors. The increase in $R_{c t}$ value can be attributed to the formation of protective film on the metal/solution interface. On the other hand, the values of Capacitances double layer $\left(C_{d l}\right)$ are decreased with increase in inhibitor concentration which is most probably is due to the decrease in local dielectric constant and/or increase in thickness of the electrical double layer, indicating that the inhibitors function by adsorption at the metal surface [25] [26]. Also the effect of temperature on the electrochemical impedance spectroscopy was studies at $30^{\circ} \mathrm{C}, 40^{\circ} \mathrm{C}, 50^{\circ} \mathrm{C}$ and $60^{\circ} \mathrm{C}$. The data in Table 1 was showed that the impedance increases as the temperature of the solution increase and this leads to an increase in the value of the charge transfer resistance $\left(R_{c t}\right)$, and this indicate to a reduction in the corrosion rate. This was lead to the increase in the inhibition efficiency from $60.75 \%$ to $91.68 \%$ for the lowest concentration and from $87.43 \%$ to $97.12 \%$ for the highest concentration of inhibitor.

\subsection{Potentiodynamic Polarization Measurements}

The potentiodynamic polarization curves of mild steel in $0.5 \mathrm{M} \mathrm{H}_{2} \mathrm{SO}_{4}$ solution with various concentrations of thiosemicarbazide at different temperature $30^{\circ} \mathrm{C}, 40^{\circ} \mathrm{C}, 50^{\circ} \mathrm{C}$ and $60^{\circ} \mathrm{C}$ are shown in Figure 2 . The electrochemical parameters such as corrosion potential $\left(E_{\text {corr }}.\right)$, corrosion current $\left(I_{\text {corr }}\right)$, anodic and cathodic Tafel slopes $($ ba and $\mathrm{bc})$ and the inhibition efficiency $(\eta \%)$ values at different temperature $30^{\circ} \mathrm{C}, 40^{\circ} \mathrm{C}, 50^{\circ} \mathrm{C}$ and $60^{\circ} \mathrm{C}$ are recorded in Table 2. The $\eta \%$ was calculated from polarization measurements according to the relation equation given below;

$$
\eta \%=\left(\frac{I_{c o r r}-I_{c o r r}^{\prime}}{I_{c o r r}}\right) \times 100
$$



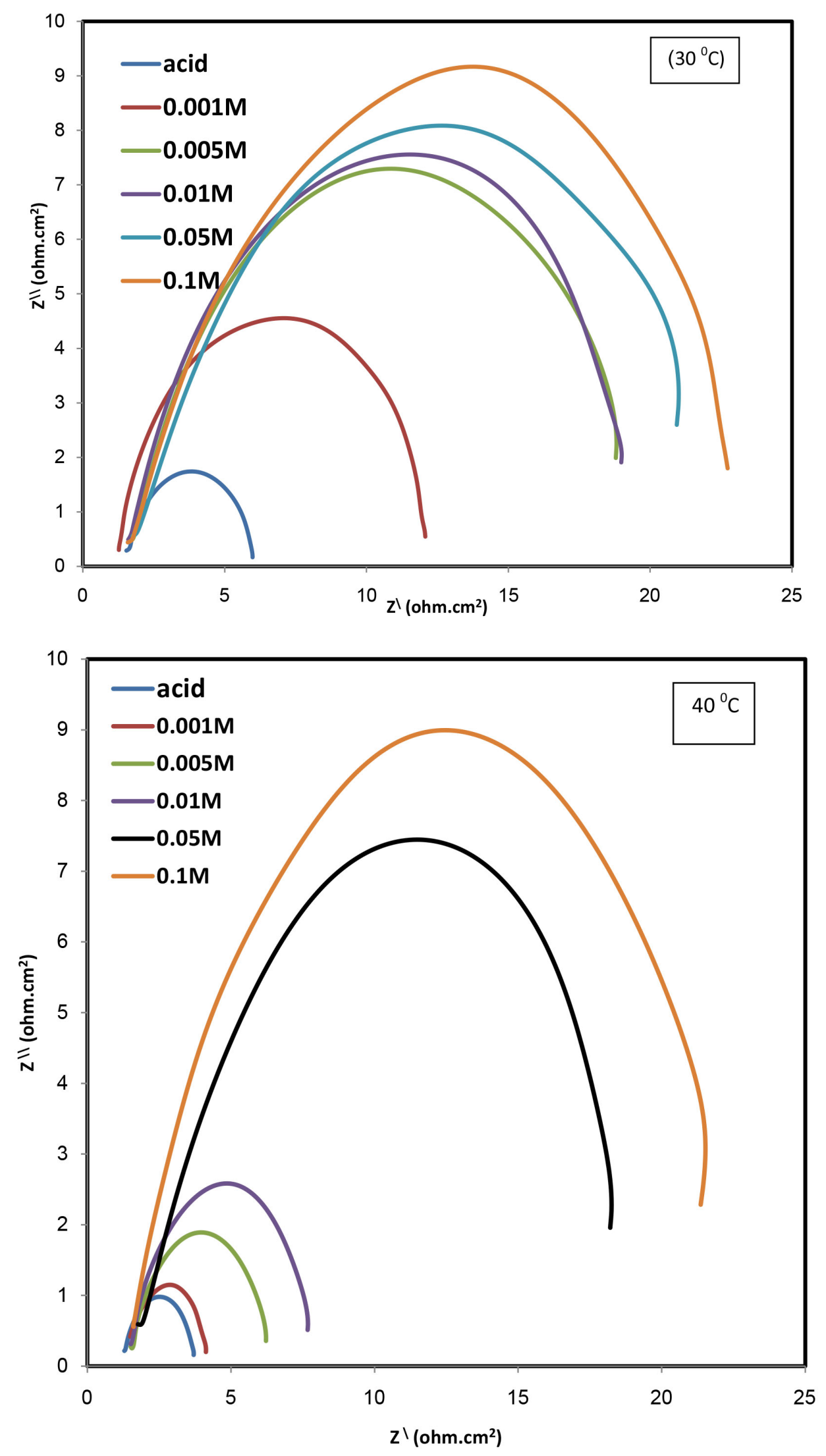

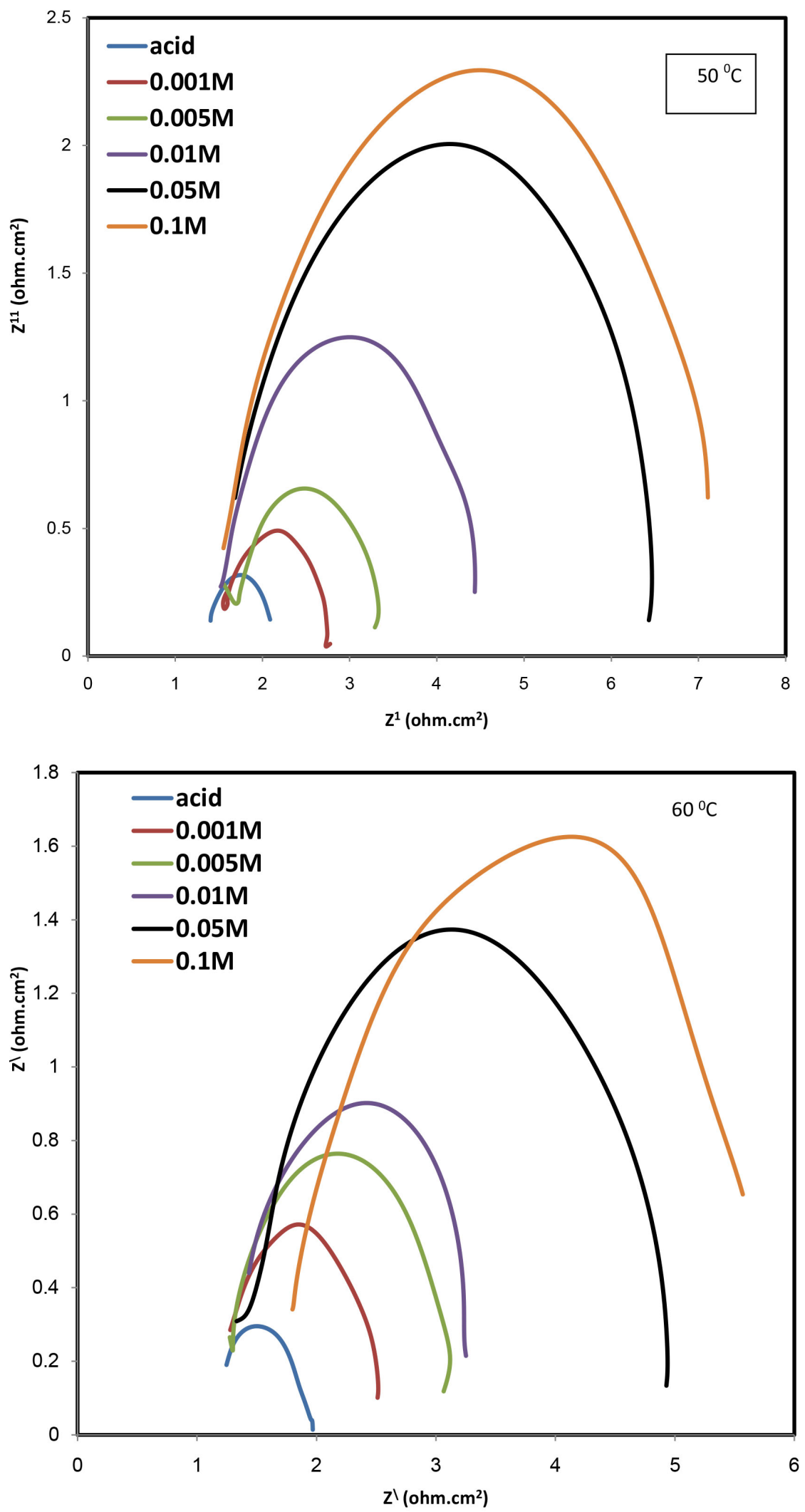

Figure 1. Nyquist diagrams for mild steel in $0.5 \mathrm{M} \mathrm{H}_{2} \mathrm{SO}_{4}$ containing different concentrations of inhibitor at different temperatures $30^{\circ} \mathrm{C}, 40^{\circ} \mathrm{C}, 50^{\circ} \mathrm{C}$ and $60^{\circ} \mathrm{C}$. 
Table 1. The impedance data of mild steel in $0.5 \mathrm{M} \mathrm{H}_{2} \mathrm{SO}_{4}$ containing different concentrations of inhibitor at different temperatures $30^{\circ} \mathrm{C}, 40^{\circ} \mathrm{C}, 50^{\circ} \mathrm{C}$ and $60^{\circ} \mathrm{C}$.

\begin{tabular}{|c|c|c|c|c|c|}
\hline Temp. & Conc. (M) & $\mathbf{R}_{\mathrm{ct}}\left(\mathrm{Ohm} \cdot \mathrm{Cm}^{2}\right)$ & $\mathbf{1} / \mathbf{R}_{\mathrm{ct}}\left(\mathrm{Ohm}^{-1} \cdot \mathrm{Cm}^{2}\right)$ & $\mathbf{C}_{\mathrm{dl}}\left(\mu \mathrm{F} \cdot \mathrm{Cm}^{2}\right)$ & $\%$ IE \\
\hline \multirow{6}{*}{$30^{\circ} \mathrm{C}$} & 0.0 & 4.507 & 0.2219 & 627.2 & --- \\
\hline & 0.001 & 11.48 & 0.0871 & 349.7 & 60.75 \\
\hline & 0.005 & 18.2 & 0.0549 & 310.9 & 75.26 \\
\hline & 0.01 & 19.27 & 0.0519 & 192.5 & 76.61 \\
\hline & 0.05 & 21.9 & 0.0474 & 177.7 & 78.64 \\
\hline & 0.1 & 35.9 & 0.0279 & 124.6 & 87.43 \\
\hline \multirow{6}{*}{$40^{\circ} \mathrm{C}$} & 0.0 & 1.001 & 0.999 & 853.9 & --- \\
\hline & 0.001 & 2.814 & 0.3553 & 565.5 & 64.43 \\
\hline & 0.005 & 4.889 & 0.2045 & 422.4 & 79.53 \\
\hline & 0.01 & 6.404 & 0.1562 & 272.1 & 84.22 \\
\hline & 0.05 & 17.75 & 0.0563 & 234.2 & 94.36 \\
\hline & 0.1 & 21.29 & 0.047 & 195.1 & 95.3 \\
\hline \multirow{6}{*}{$50^{\circ} \mathrm{C}$} & 0.0 & 0.3011 & 3.3212 & 936.4 & --- \\
\hline & 0.001 & 1.298 & 0.7704 & 647 & 76.8 \\
\hline & 0.005 & 1.784 & 0.5605 & 533 & 83.08 \\
\hline & 0.01 & 2.989 & 0.3346 & 423.1 & 89.93 \\
\hline & 0.05 & 5.29 & 0.189 & 354.6 & 94.31 \\
\hline & 0.1 & 6.038 & 0.1656 & 256.1 & 95.01 \\
\hline \multirow{6}{*}{$60^{\circ} \mathrm{C}$} & 0.0 & 0.12 & 8.3333 & 1114 & --- \\
\hline & 0.001 & 1.442 & 0.6935 & 959.7 & 91.68 \\
\hline & 0.005 & 2.223 & 0.44498 & 804.6 & 94.6 \\
\hline & 0.01 & 2.016 & 0.496 & 714.1 & 94.05 \\
\hline & 0.05 & 3.816 & 0.262 & 694 & 96.86 \\
\hline & 0.1 & 4.192 & 0.2403 & 517.3 & 97.12 \\
\hline
\end{tabular}

where $I_{\text {corr }}$ and $I_{\text {corr }}^{\prime}$ are corrosion current densities in the absence and presence of the inhibitor, respectively. Figure 2 shows that the presence of the inhibitor, both anodic and cathodic curves are shifted and the shift depends on the concentration of the inhibitor. The polarization curves for the mild steel in the absence of inhibitor show that the current density in the anodic region increases rapidly indicating extensive dissolution of metal. This led to both the anodic metal dissolution and cathodic hydrogen evolution reactions were inhibited after the addition of thiosemicarbazide to the aggressive medium. Table 2 shows that there is irregular displacement in the corrosion potential (Ecorr.) values for mild steel are varied in irregular shape; this behavior was previously observed in many others studies [27]-[29]. Also, it is clear that the values of $b_{a}$ and $b_{c}$ are decreased with increase in the concentration of thiosemicarbazide; these results indicate that thiosemicarbazide acts as the mixed type corrosion inhibitor. The inhibitor molecules are first adsorbed on the surface of the mild steel and blocking the available reaction sites [30]. The surface coverage increases as the inhibitor concentrations increase. The presence of defects on the metal surface statements free access to $\mathrm{H}^{+}$ions [31] and a significant dissolution of metal carry out, followed by desorption of the inhibitor film from the metal surface [32]. This observed phenomenon is usually described as the corrosion inhibition of the metal with the development of a protective layer of adsorbed species at the metal surface [33].

Also the polarization measurements were taken at different temperatures in the absence and presence of various concentrations $(0.001,0.005,0.01,0.05,0.1 \mathrm{M})$ of the inhibitor. Figure 2 shows that the corrosion rate of mild steel rapidly increases with increasing temperature over the range $\left(30^{\circ} \mathrm{C}-60^{\circ} \mathrm{C}\right)$ in presence of the inhibitor. Table 2 observed that the corrosion rate $\left(I_{\text {corr }}\right)$ of the mild steel in the presence of the inhibitor decreases with increasing its concentration and increases with increasing the temperature, whereas its efficiency increases with 

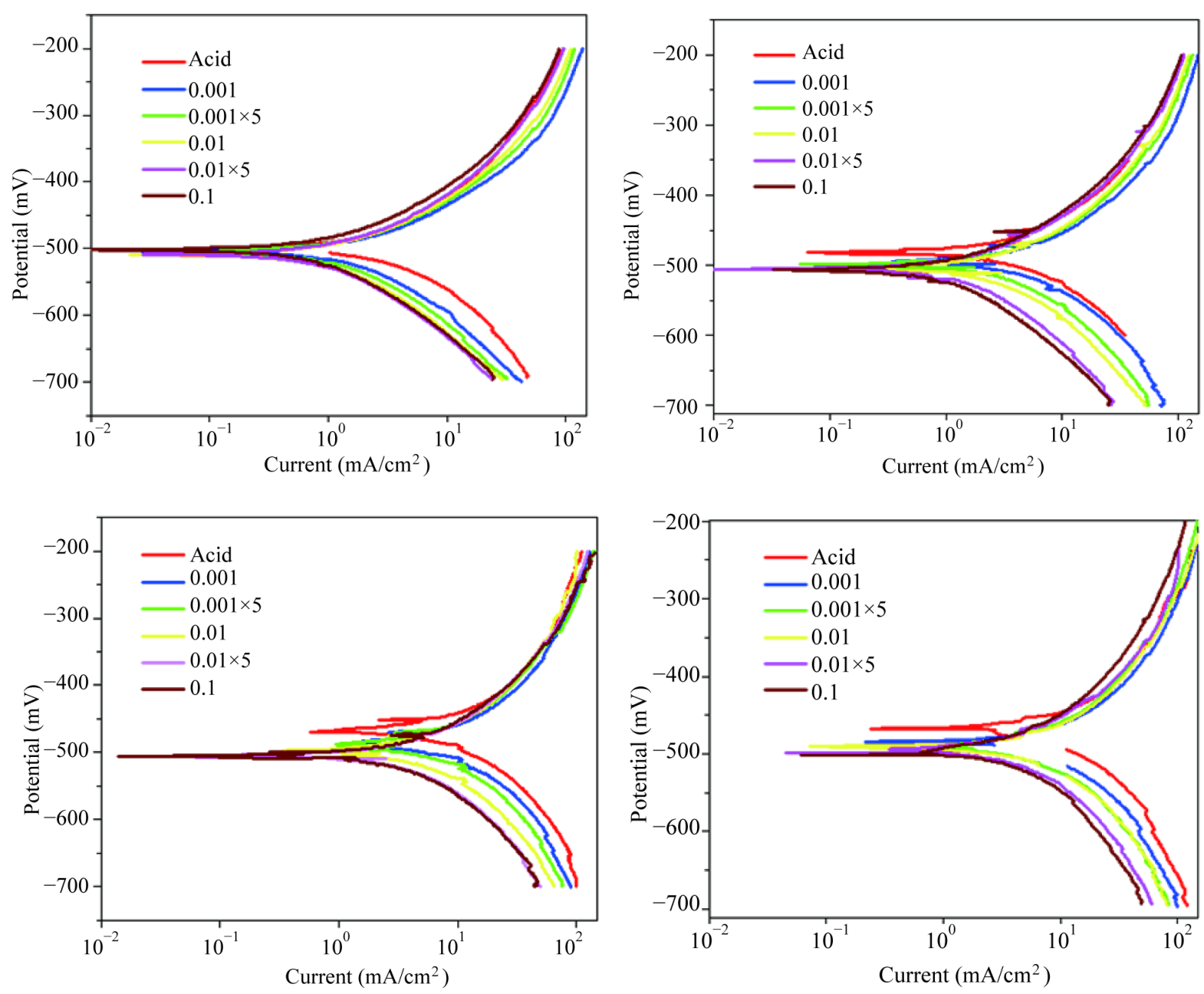

Figure 2. Polarization curves of mild steel in $0.5 \mathrm{M} \mathrm{H}_{2} \mathrm{SO}_{4}$ containing different concentrations of inhibitor at different temperatures $30^{\circ} \mathrm{C}, 40^{\circ} \mathrm{C}, 50^{\circ} \mathrm{C}$ and $60^{\circ} \mathrm{C}$.

increasing both its concentration and the temperature. And this was lead to the increase in the inhibition efficiency from $46.72 \%$ for the lowest concentration of inhibitor to $73.92 \%$ and from $87.41 \%$ for the highest concentration of inhibitor to $91.41 \%$. These results are correlated with the data obtained from the impedance measurements.

\subsection{Adsorption Isotherm and Thermodynamic Consideration}

In order to get a better understanding of the electrochemical process on the metal surface, adsorption characteristics were also studied for a corrosive media. This process is closely related to the adsorption of the inhibitor molecules and adsorption is known to depend on the chemical structure. Adsorption isotherms are very important in determining the mechanism of organic electrochemical reactions. The adsorption of organic adsorbate on the surface of metal is regarded as substitutional adsorption process between the organic compound in the aqueous phase (Org. $)_{\text {aq }}$ and the water molecules adsorbed on the metal surface $\left(\mathrm{H}_{2} \mathrm{O}\right)_{\text {ads }}$ according to following process [34]:

$$
\operatorname{Org}_{\text {sol }}+x\left(\mathrm{H}_{2} \mathrm{O}\right)_{\text {ads }} \Leftrightarrow \operatorname{Org}_{\text {ads }}+x\left(\mathrm{H}_{2} \mathrm{O}\right)_{\text {sol }}
$$

where $x$ is the number of water molecules replaced by one organic molecule. The adsorption process of inhibitors are influenced by the chemical structures of organic compounds, the nature and surface charge of metal, the distribution of charge in molecule and the type of aggressive media [35]. One of the clearest examples thereof is 
Table 2. Polarization data of mild steel in $0.5 \mathrm{M} \mathrm{H}_{2} \mathrm{SO}_{4}$ containing different concentrations of inhibitor at different temperatures $30^{\circ} \mathrm{C}, 40^{\circ} \mathrm{C}, 50^{\circ} \mathrm{C}$ and $60^{\circ} \mathrm{C}$.

\begin{tabular}{|c|c|c|c|c|c|c|}
\hline Temp. & Conc. (M) & $\mathbf{E}_{\text {corr }}(\mathrm{mV})$ & $\mathbf{I}_{\text {corr }}\left(\mathrm{mA} / \mathrm{cm}^{2}\right)$ & $\mathbf{b}_{\mathbf{a}}(\mathrm{V} /$ decade $)$ & $\mathbf{b}_{\mathbf{c}}(\mathrm{V} /$ decade $)$ & $\eta \%$ \\
\hline \multirow{6}{*}{$30^{\circ} \mathrm{C}$} & 0.0 & -503.99 & 10.567 & 0.0589 & 0.1139 & --- \\
\hline & 0.001 & -504.09 & 5.6301 & 0.0579 & 0.1194 & 46.72 \\
\hline & 0.005 & -506.89 & 4.1856 & 0.057 & 0.0849 & 60.39 \\
\hline & 0.01 & -509.89 & 3.4243 & 0.0494 & 0.0867 & 69.31 \\
\hline & 0.05 & -510.05 & 2.3838 & 0.0481 & 0.08513 & 77.44 \\
\hline & 0.1 & -511.97 & 1.33 & 0.0493 & 0.1251 & 87.41 \\
\hline \multirow{6}{*}{$40^{\circ} \mathrm{C}$} & 0.0 & -482.44 & 16.146 & 0.0521 & 0.1248 & --- \\
\hline & 0.001 & -497.08 & 7.3765 & 0.0536 & 0.0922 & 54.31 \\
\hline & 0.005 & -501.73 & 5.4658 & 0.0689 & 0.0926 & 66.15 \\
\hline & 0.01 & -504.82 & 4.6543 & 0.065 & 0.0852 & 71.17 \\
\hline & 0.05 & -505.11 & 3.1598 & 0.0473 & 0.0915 & 80.43 \\
\hline & 0.1 & -508.71 & 2.0547 & 0.0649 & 0.1461 & 87.77 \\
\hline \multirow{6}{*}{$50^{\circ} \mathrm{C}$} & 0.0 & -468.56 & 22.513 & 0.0526 & 0.124 & --- \\
\hline & 0.001 & -485.46 & 8.0209 & 0.0629 & 0.0947 & 64.37 \\
\hline & 0.005 & -495.22 & 6.4543 & 0.063 & 0.1617 & 71.33 \\
\hline & 0.01 & -499.52 & 4.8444 & 0.054 & 0.1659 & 78.48 \\
\hline & 0.05 & -506.54 & 4.2806 & 0.0493 & 0.1014 & 80.99 \\
\hline & 0.1 & -508.02 & 2.6613 & 0.0481 & 0.1144 & 88.18 \\
\hline \multirow{6}{*}{$60^{\circ} \mathrm{C}$} & 0.0 & -456.61 & 42.347 & 0.069 & 0.1417 & --- \\
\hline & 0.001 & -483.52 & 11.046 & 0.0473 & 0.1252 & 73.92 \\
\hline & 0.005 & -492.49 & 8.3707 & 0.0498 & 0.1024 & 73.92 \\
\hline & 0.01 & -495.58 & 6.2329 & 0.0533 & 0.0996 & 85.28 \\
\hline & 0.05 & -497.08 & 5.6662 & 0.0631 & 0.1185 & 86.62 \\
\hline & 0.1 & -499.95 & 3.6366 & 0.0484 & 0.1158 & 91.41 \\
\hline
\end{tabular}

the observation of endothermic adsorption which indisputably identifies chemisorption, as physisorption is an intrinsically exothermic process. The values of $K$ (Table 3) were studied by fitting different adsorption isotherms, including the kinetic model, Flory-Huggins and Langmuir models. Also the correlation coefficient $\left(R^{2}\right)$ was used to choose the isotherm that is the best fit with the experimental data. Good agreement between the two models (kinetic and Flory-Huggins) obtained for all temperatures. The binding constant ' $K$ ' increases as the temperature increases, giving evidence for increasing surface coverage, $\Theta$, as the temperature increases. Large values of ' $K$ ' imply improved inhibition efficiency, i.e. strong electrical interactions between the double layer existing at the phase boundary and the adsorbate. Both ' $y$ ' and ' $K$ ' are functions of the nature of the inhibitor, the type of the model used, the nature of the aggressive medium, and temperature.

The thermodynamic parameters $\Delta G_{a d s}^{\circ}, \Delta H^{\circ}$ ads, and $\Delta S_{a d s}^{\circ} \&$ can be obtained from the dependence of the equilibrium constant (obtained from the kinetic model) on temperature by linear the following equation [36]:

$$
\operatorname{In} K=-\Delta H^{\circ} \text { ads } / R T+\Delta S_{\text {ads }}^{\circ} / R
$$

where, $\Delta H^{\circ}{ }_{a d s}, \Delta S^{\circ}$ ads and $\Delta G^{\circ}$ ads are the enthalpy, entropy and Gibbs free energy changes, respectively and $T$ is the temperature in Kelvin, $\mathrm{R}$ is the gas constant $\left(\approx 8.314 \mathrm{~J} \cdot \mathrm{K}^{-1} \cdot \mathrm{mol}^{-1}\right)$. In the system where temperature increase result in higher protection efficiency, a positive $\Delta H^{\circ}$ ads results. This is interpreted on the basis that stronger surface interaction result at higher temperatures. A plot of $\operatorname{In} K$ vs. (1/T) gives a straight line with a slope of $\left(-\Delta H^{\circ}{ }_{a d s} / R\right)$ and intercept of $\left(\Delta S^{\circ}{ }_{a d s} / R\right)$. Value of $\Delta H^{\circ}$ ads was calculated and was equal to $110.2 \mathrm{~kJ} \cdot \mathrm{mol}^{-1}$ and the value of $\Delta S^{\circ}$ ads calculated as $438 \mathrm{~J} \cdot \mathrm{mol}^{-1} \cdot \mathrm{K}^{-1}$. The $\Delta G^{\circ}$ ads value is calculated by the use of the following expression [36]. 
Table 3. Curve fitting data of the inhibitor to Langmuir, Flory-Huggind isotherm and kinetic model.

\begin{tabular}{cccccccccc}
\hline Temperature & \multicolumn{2}{c}{ Langmuir } & \multicolumn{3}{c}{ Flory-Huggins } & \multicolumn{3}{c}{ Kinitic model } \\
\hline$\left.{ }^{\circ} \mathbf{C}\right)$ & $\mathbf{K}$ & $\mathbf{R}^{\mathbf{2}}$ & $\mathbf{x}$ & $\mathbf{K}$ & $\mathbf{R}^{\mathbf{2}}$ & $\mathbf{1 / y}$ & $\mathbf{K}$ & $\mathbf{R}^{\mathbf{2}}$ \\
30 & 73.589 & 0.88 & 1.931 & 1976.97 & 0.95 & 1.95 & 2909.89 & 0.96 \\
40 & 208.99 & 0.98 & 3.8977 & 5147.54 & 0.98 & 3.66 & 6627.82 & 0.99 \\
50 & 225.72 & 0.87 & 2.5766 & 10055.4 & 0.97 & 2.47 & 13699.5 & 0.97 \\
60 & 410 & 0.87 & 4.3505 & $1.3 \mathrm{E}+07$ & 0.96 & 3.95 & $1.1 \mathrm{E}+07$ & 0.98 \\
\hline
\end{tabular}

Table 4. $\Delta \mathrm{G}_{\text {ads }}$ values for the adsorption of the inhibitor on mild steel surface calculated from the kinetic model at different temperatures.

\begin{tabular}{ccc}
\hline Temperature & $\Delta \boldsymbol{G}_{a d s}^{\circ}$ \\
\hline$\left({ }^{\circ} \mathrm{C}\right)$ & $\left(\mathrm{kJ} \cdot \mathrm{mole}^{-1}\right)$ \\
30 & -22.51 \\
40 & -26.89 \\
50 & -31.27 \\
60 & -35.65 \\
\hline
\end{tabular}

$$
\Delta G_{a d s}^{\circ}=\Delta H^{\circ}{ }_{a d s}-T \Delta S_{a d s}^{\circ}
$$

The resulting values of this expression are given in Table 4 and generally, $\Delta G_{a d s}^{\circ}$ values until $-20 \mathrm{~kJ} \cdot \mathrm{mol}^{-1}$ are associated with electrostatic interactions between the charged molecules and the charged metal surface (physisorption), whereas those below $-40 \mathrm{~kJ} \cdot \mathrm{mol}^{-1}$ involve the sharing or transfer of charge from the organic molecules to the metal surface to form a coordinate covalent bond (chemisorption) [37]. The $\Delta G^{\circ}$ ads values obtained for the inhibitor at the four temperatures are between -22.6 and $-35.6 \mathrm{~kJ} \cdot \mathrm{mol}^{-1}$. These values indicate that the adsorption process of the evaluated inhibitor on the mild steel surface may involve complex interactions (both physical and chemical adsorption) [38].

\subsection{Scanning Electron Microscopy (SEM) Study}

Surface morphology of mild steel was studied by scanning electron microscopy after $24 \mathrm{~h}$ immersion in $0.5 \mathrm{M}$ $\mathrm{H}_{2} \mathrm{SO}_{4}$ before and after addition of the inhibitor at $30^{\circ} \mathrm{C}$. Figure 3(a) showed the SEM obtained of polished steel without being exposed to the corrosive environment and it clearer that that the mild steel sample before immersion seems smooth and shows some abrading scratches on the surface while, Figure 3(b) showed strongly damaged on mild steel surface due to the formation of corrosion products after immersion in $0.5 \mathrm{M} \mathrm{H}_{2} \mathrm{SO}_{4}$ solution. And shows that an aggressive attack of the corroding medium on the mild steel surface. In contrast, Figure 3(c) SEM image of mild steel surface after immersion in $0.5 \mathrm{M} \mathrm{H}_{2} \mathrm{SO}_{4}$ in the presence of $0.1 \mathrm{M}$ of thiosemicarbazide extract the mild steel surface was corroded only negligibly. The result was an enhancement of surface coverage on the mild steel surface such that there was a decrease in contact between the mild steel and the aggressive medium. Thus, a good absorptive protection layer can efficiently inhibit the corrosion of mild steel.

\section{Conclusions}

1) The corrosion of MS in $0.5 \mathrm{M} \mathrm{H}_{2} \mathrm{SO}_{4}$ solution can be inhibited by the use of thiosemicarbazide compound.

2) As the concentration of thiosemicarbazide increases, the inhibition efficiency of MS increases.

3) The electrochemical impedance spectroscopy shows that, the impedance increases as the temperature increases and this leads to an increase in the charge transfer resistance $\left(\mathrm{R}_{\mathrm{ct}}\right)$, and this indicates to a reduction in the corrosion rate.

4) The polarization data indicate that, the corrosion rate $\left(\mathrm{I}_{\text {corr }}\right)$ of the mild steel in the presence of the inhibitor decreases with increasing its concentration and increases with increasing the temperature, whereas its efficiency increases with increasing both its concentration and the temperature.

5) The adsorption of thiosemicarbazide molecules on the metal surface from $0.5 \mathrm{~mol} / \mathrm{L} \mathrm{H}_{2} \mathrm{SO}_{4}$ solution 

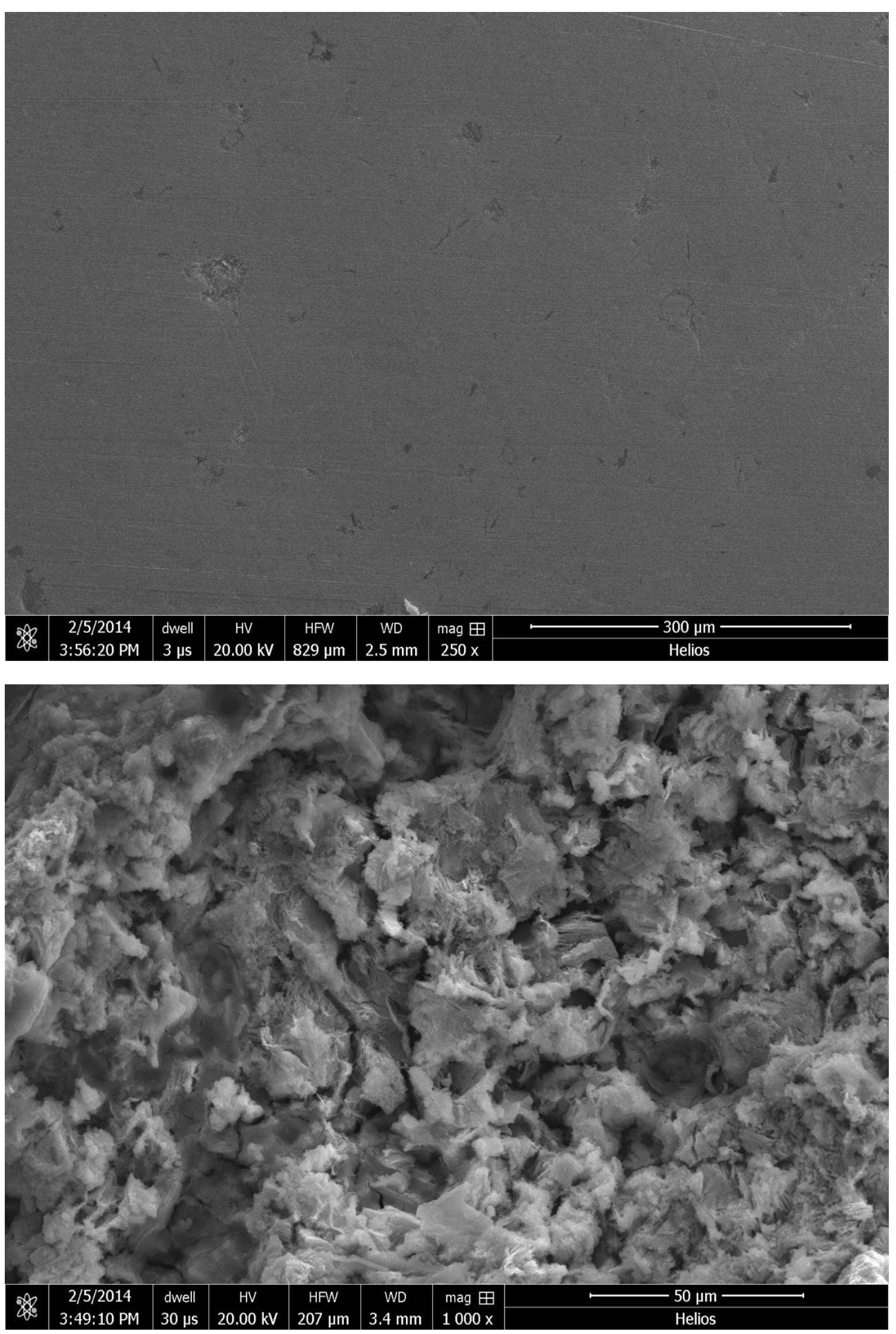


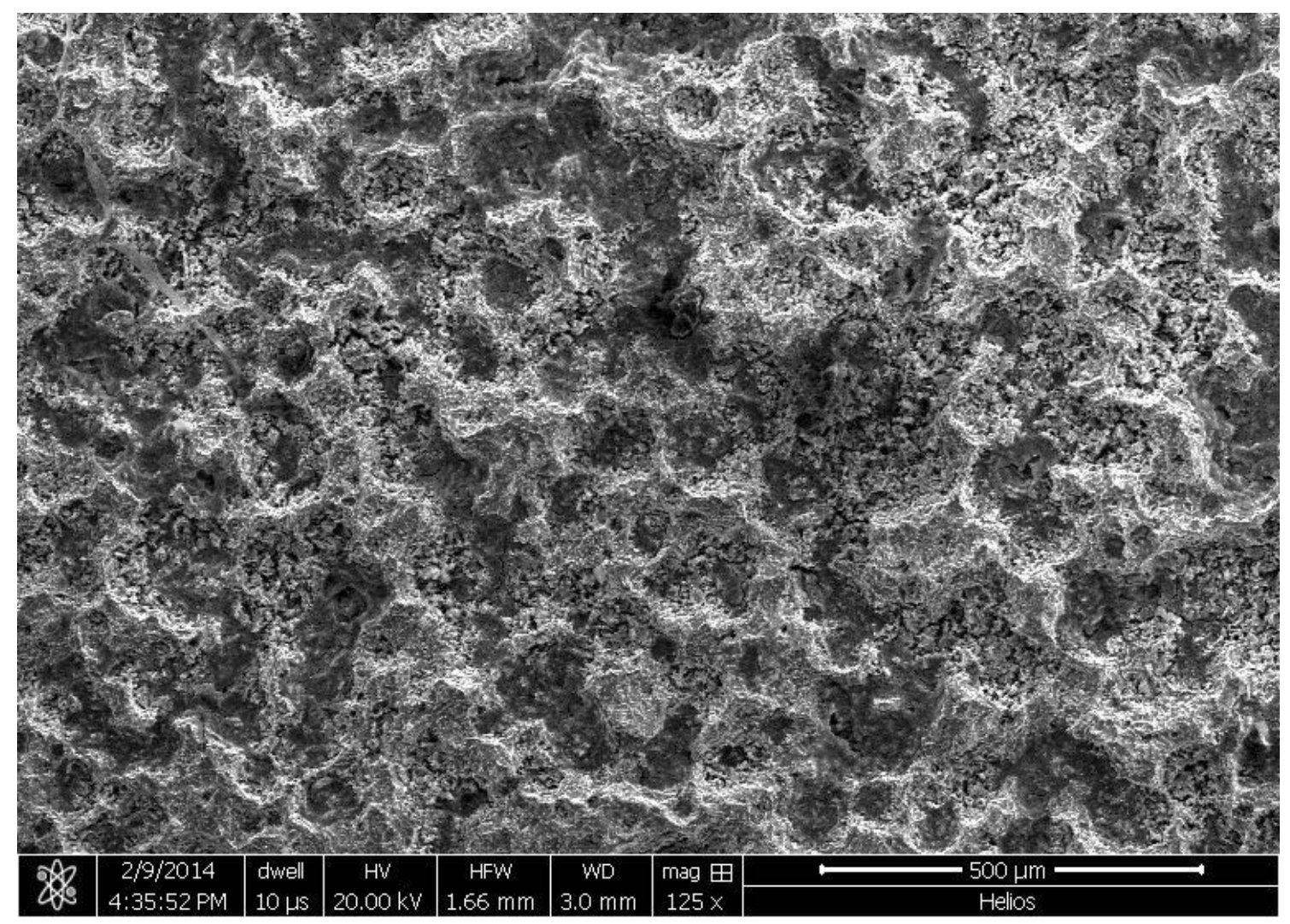

Figure 3. SEM images of mild steel samples: (a) polishing surface (b) after immersion in $0.5 \mathrm{M} \mathrm{H}_{2} \mathrm{SO}_{4}$ solution without inhibitor (c) after immersion in $0.5 \mathrm{M} \mathrm{H}_{2} \mathrm{SO}_{4}$ solution in the presence of $0.1 \mathrm{M}$ thiosemicarbazide.

obeyed Langmuir adsorption isotherm model.

6) Surface morphological studied with SEM showed that a film of inhibitor was formed on the electrode surface.

\section{References}

[1] Obot, I.B. and Obi-Egbedi, N.O. (2010) Adsorption Properties and Inhibition of Mild Steel Corrosion in Sulphuric Acid Solution by Ketoconazole: Experimental and Theoretical Investigation. Corrosion Science, 52, 198-204. http://dx.doi.org/10.1016/j.corsci.2009.09.002

[2] Solmaz, R. (2014) Investigation of Adsorption and Corrosion Inhibition of Mild Steel in Hydrochloric Acid Solution by 5-(4-Dimethylaminobenzylidene) Rhodanine. Corrosion Science, 79, 169-176. http://dx.doi.org/10.1016/j.corsci.2013.11.001

[3] Abd El-Nabey, B.A., El-Gamal, M., Khamis, E. and Mahgoub, F. (1987) Acid Corrosion of Steel in Water-Dimethyl Formamide Solutions. Surface and Coatings Technology, 31, 89-101. http://dx.doi.org/10.1016/0257-8972(87)90156-3

[4] Mahgoub, F.M., Abdel-Nabey, B.A. and El-Samadisy, Y.A. (2010) Adopting a Multipurpose Inhibitor to Control Corrosion of Ferrous Alloys in Cooling Water Systems. Materials Chemistry and Physics, 120, 104-108. http://dx.doi.org/10.1016/j.matchemphys.2009.10.028

[5] Awada, M.K., Mahgoub, F.M. and El-iskandarani, M.M. (2000) Theoretical Studies of the Effect of Structural Parameters on the Inhibition Efficiencies of Mercapto-1,2,4-Triazoline Derivatives. Journal of Molecular Structure (Theochem), 531, 105-117. http://dx.doi.org/10.1016/S0166-1280(00)00437-1

[6] Solmaz, R., Altunbas, E. and Kardas, G. (2011) Investigation of Adsorption and Corrosion Inhibition Effect of 1,10Thiocarbonyldiimidazole on Mild Steel in Hydrochloric Acid Solution. Protection of Metals and Physical Chemistry of Surfaces, 47, 262-269. http://dx.doi.org/10.1134/s2070205111020183

[7] Solmaz, R., Mert, M.E., Kardas, G., Yazici, B. and Erbil, M. (2008) Adsorption and Corrosion Inhibition Effect of 1,10-Thiocarbonyldiimidazole on Mild Steel in $\mathrm{H}_{2} \mathrm{SO}_{4}$ Solution and Synergistic Effect of Iodide Ion. Acta Physico- 
Chimica Sinica, 24, 1185-1191. http://dx.doi.org/10.1016/S1872-1508(08)60053-4

[8] Doner, A., Sahin, E.A., Kardas, G. and Serindag, O. (2013) Investigation of Corrosion Inhibition Effect of 3-[(2-Hydroxy-Benzylidene)-Amino]-2-Thioxo-Thiazolidin-4-One on Corrosion of Mild Steel in the Acidic Medium. Corrosion Science, 66, 278-284. http://dx.doi.org/10.1016/j.corsci.2012.09.030

[9] Ita, B.I. and Offiong, O.E. (2001) The Study of the Inhibitory Properties of Benzoin, Benzil, Benzoin- (4-Phenylthiosemicarbazone) and Benzil-(4-Phenylthiosemicarbazone) on the Corrosion of Mild Steel in Hydrochloric Acid. Materials Chemistry and Physics, 70, 330-335. http://dx.doi.org/10.1016/S0254-0584(00)00476-4

[10] Arab, S.T. and Emran, K.M. (2008) Structure Effect of Some Thiosemicarbazone Derivatives on the Corrosion Inhibition of $\mathrm{Fe}_{78} \mathrm{~B}_{13} \mathrm{Si}_{9}$ Glassy Alloy in $\mathrm{Na}_{2} \mathrm{SO}_{4}$ Solution. Materials Letters, 62, 1022-1032. http://dx.doi.org/10.1016/j.matlet.2007.05.088

[11] Kandemirli, F. and Sagdinc, S. (2007) Theoretical Study of Corrosion Inhibition of Amides and Thiosemicarbazones. Corrosion Science, 49, 2118-2130. http://dx.doi.org/10.1016/j.corsci.2006.10.026

[12] Jacob, K.S. and Parameswaran, G. (2010) Corrosion Inhibition of Mild Steel in Hydrochloric Acid Solution by Schiff Base Furoin Thiosemicarbazone. Corrosion Science, 52, 224-228. http://dx.doi.org/10.1016/j.corsci.2009.09.007

[13] Khaled, K.F. (2010) Electrochemical Behavior of Nickel in Nitric Acid and Its Corrosion Inhibition Using Some Thiosemicarbazone Derivatives. Electrochimica Acta, 55, 5375-5383. http://dx.doi.org/10.1016/j.electacta.2010.04.079

[14] Mohan, P. and Kalaignan1, G.P. (2013) 4-Bis (2-Nitrobenzylidene) Thiosemicarbazide as Effective Corrosion Inhibitor for Mild Steel. Journal of Materials Science and Technology, 29, 1096-1100. http://dx.doi.org/10.1016/i.jmst.2013.07.006

[15] Xu, B., Yang, W., Liu, Y., Yin, X., Gong, W. and Chen, Y. (2014) Experimental and Theoretical Evaluation of Two Pyridinecarboxaldehyde Thiosemicarbazone Compounds as Corrosion Inhibitors for Mild Steel in Hydrochloric Acid Solution. Corrosion Science, 78, 260-268. http://dx.doi.org/10.1016/j.corsci.2013.10.007

[16] Casas, J.S., Garcia-Tasende, M.S. and Sordo, J. (2000) Main Group Metal Complexes of Semicarbazones and Thiosemicarbazones. A Structural Review. Coordination Chemistry Reviews, 209, 197-261. http://dx.doi.org/10.1016/S0010-8545(00)00363-5

[17] Lobana, T.S., Sharma, R., Bawa, G. and Khanna, S. (2009) Bonding and Structure Trends of Thiosemicarbazone Derivatives of Metals-An Overview. Coordination Chemistry Reviews, 253, 977-1055. http://dx.doi.org/10.1016/j.ccr.2008.07.004

[18] Bisceglie, F., Monte, G.D., Tarasconi, P. and Pelosi, G. (2015) Synthesis and Characterization of 4-Fluorobenzaldehyde Thiosemicarbazone Derivatives as Corrosion Inhibitors. Inorganica Chimica Acta, 434, 143-149. http://dx.doi.org/10.1016/i.ica.2015.05.020

[19] Poornima, T., Nayak, J. and Shetty, A.N. (2011) Effect of 4-(N,N-Diethylamino)benzaldehyde Thiosemicarbazone on the Corrosion of Aged 18 Ni 250 Grade Maraging Steel in Phosphoric Acid Solution. Corrosion Science, 53, 36883696. http://dx.doi.org/10.1016/j.corsci.2011.07.014

[20] Karakus, N. and Sayin, K. (2015) The Investigation of Corrosion Inhibition Efficiency on Some Benzaldehyde Thiosemicarbazones and Their Thiole Tautomers: Computational Study. Journal of the Taiwan Institute of Chemical Engineers, 48, 95-102. http://dx.doi.org/10.1016/j.jtice.2014.10.024

[21] Khaled, K.F. (2008) Adsorption and Inhibitive Properties of a New Synthesized Guanidine Derivative on Corrosion of Copper in $0.5 \mathrm{M} \mathrm{H}_{2} \mathrm{SO}_{4}$. Applied Surface Science, 255, 1811-1818. http://dx.doi.org/10.1016/j.apsusc.2008.06.030

[22] Emregul, K.C., Duzgun, E. and Atakol, O. (2006) The Application of Some Polydentate Schiff Base Compounds Containing Aminic Nitrogens as Corrosion Inhibitors for Mild Steel in Acidic Media. Corrosion Science, 48, 3243-3260. http://dx.doi.org/10.1016/j.corsci.2005.11.016

[23] Tebbji, K., Faska, N., Tounsi, A., Oudda, H., Benkaddour, M. and Hammouti, B. (2007) The Effect of Some Lactones as Inhibitors for the Corrosion of Mild Steel in 1 M Hydrochloric Acid. Materials Chemistry and Physics, 106, 260267. http://dx.doi.org/10.1016/j.matchemphys.2007.05.046

[24] Da Rocha, J.C., Gomes, J.A.C.P. and D’Elia, E. (2010) Corrosion Inhibition of Carbon Steel in Hydrochloric Acid Solution by Fruit Peel Aqueous Extracts. Corrosion Science, 52, 2341-2348. http://dx.doi.org/10.1016/j.corsci.2010.03.033

[25] Prabhu, R.A., Venkatesha, T.V., Shanbhag, A.V., Kulkarni, G.M. and Kalkhambkar, R.G. (2008) Inhibition Effects of Some Schiff's Bases on the Corrosion of Mild Steel in Hydrochloric Acid Solution. Corrosion Science, 50, 3356-3362. http://dx.doi.org/10.1016/j.corsci.2008.09.009

[26] Tang, Y., Yang, X., Yang, W., Chen, Y. and Wan, R. (2010) Experimental and Molecular Dynamics Studies on Corrosion Inhibition of Mild Steel by 2-Amino-5-phenyl-1,3,4-thiadiazole. Corrosion Science, 52, 242-249. http://dx.doi.org/10.1016/j.corsci.2009.09.010 
[27] Farooqi, I., Quraishi, M. and Saini, P. (1997) Eurocorrosion, 97, 347.

[28] Fouda, A. and El-Semongym, M. (1982) The Effect of Some Amino-Acids on the Corrosion of Aluminum in Hcl Solution. Journal of the Indian Chemical Society, 59, 89-92.

[29] Kertit, S., Aride, J., Ben-Bachir, A., Srhiri, A. and Etman, M. (1994) Corrosion Inhibition of Amorphous FeBSiC Alloy in $1 \mathrm{M} \mathrm{HCl}$ by 3-Amino-1,2,4-triazole. Journal of Applied Electrochemistry, 24, 1139-1145. http://dx.doi.org/10.1007/BF00241312

[30] Fuchs-Godec, R. (2006) The Adsorption, CMC Determination and Corrosion Inhibition of Some $N$-Alkyl Quaternary Ammonium Salts on Carbon Steel Surface in $2 \mathrm{M} \mathrm{H}_{2} \mathrm{SO}_{4}$. Colloids and Surfaces A: Physicochemical and Engineering Aspects, 280, 130-139. http://dx.doi.org/10.1016/i.colsurfa.2006.01.046

[31] Chetouani, A., Hammouti, B., Benhadda, T. and Daoudi, M. (2005) Inhibitive Action of Bipyrazolic Type Organic Compounds towards Corrosion of Pure Iron in Acidic Media. Applied Surface Science, 249, 375-385. http://dx.doi.org/10.1016/i.apsusc.2004.12.034

[32] El Mehdi, B., Mernari, B., Traisnel, M., Bentiss, F. and Lagrenee, M. (2003) Synthesis and Comparative Study of the Inhibitive Effect of Some New Triazole Derivatives towards Corrosion of Mild Steel in Hydrochloric Acid Solution. Materials Chemistry and Physics, 77, 489-496. http://dx.doi.org/10.1016/S0254-0584(02)00085-8

[33] Lorenz, W.J. and Mansfeld, F. (1986) Corrosion Science, 31, 467-476.

[34] Bockris, J.O'.M. and Reddy, A.K.N. (1976) Modern Electrochemistry. Vol. 2, Plenum Publishing Corporation, New York.

[35] Saleh, M.R. and Sham El-Di, A.M. (1972) Efficiency of Organic Acids and Their Anions in Retarding the Dissolution of Aluminium. Corrosion Science, 12, 689-697. http://dx.doi.org/10.1016/S0010-938X(72)91188-2

[36] Badie, A.M. and Moh, K.N. (2009) Corrosion Mechanism of Low-Carbon Steel in Industrial Water and Adsorption Thermodynamics in the Presence of Some Plant Extracts. Journal of Materials Engineering and Performance, 18, 1264-1271. http://dx.doi.org/10.1007/s11665-009-9378-x

[37] Bahrami, M.J., Hosseini, S.M.A. and Pilvar, P. (2010) Experimental and Theoretical Investigation of Organic Compounds as Inhibitors for Mild Steel Corrosion in Sulfuric Acid Medium. Corrosion Science, 52, 2793-2803. http://dx.doi.org/10.1016/j.corsci.2010.04.024

[38] Ahamad, I., Prasad, R. and Quraishi, M.A. (2010) Thermodynamic, Electrochemical and Quantum Chemical Investigation of Some Schiff Bases as Corrosion Inhibitors for Mild Steel in Hydrochloric Acid Solutions. Corrosion Science, 52, 933-942. http://dx.doi.org/10.1016/j.corsci.2009.11.016 